\title{
Correction
}

\section{Correction to: Human cytomegalovirus DNA and immediate early protein $1 / 2$ are highly associated with glioma and prognosis}

\author{
Le Wen ${ }^{1,2}$, Fei Zhao ${ }^{3}$, Yong Qiu ${ }^{4}$, Shuang Cheng ${ }^{2}$, Jin-Yan Sun ${ }^{2}$, Wei Fang ${ }^{2}$, Simon Rayner ${ }^{5}$,

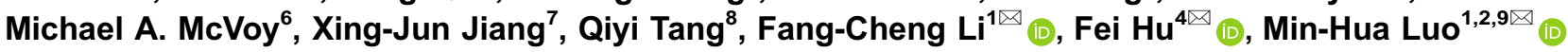 \\ 1 Joint Center of Translational Precision Medicine, Guangzhou Institute of Pediatrics, Guangzhou Women and Children's \\ Medical Center, Guangzhou 510623, China \\ 2 State Key Laboratory of Virology, CAS Center for Excellence in Brain Science and Intelligence Technology, Wuhan Institute of \\ Virology, Wuhan 430071, China \\ ${ }^{3}$ Chinese Institute for Brain Research, Beijing 102206, China \\ ${ }^{4}$ Wuhan Brain Hospital, Ministry of Transportation, Wuhan 430010, China \\ ${ }^{5}$ Department of Medical Genetics, Oslo University Hospital and University of Oslo, Oslo, Norway \\ ${ }^{6}$ Department of Pediatrics, Virginia Commonwealth University School of Medicine, Richmond, Virginia, USA \\ ${ }^{7}$ Department of Neurosurgery, Xiangya Hospital, Central South University, Changha 410008, China \\ ${ }^{8}$ Department of Microbiology, Howard University College of Medicine, Washington, DC, USA \\ ${ }^{9}$ University of Chinese Academy of Sciences, Beijing 100049, China \\ $\square$ Correspondence: sjwklfc@126.com (F.-C. Li), neuron111@163.com (F. Hu), luomh@wh.iov.cn (M.-H. Luo)
}

\section{CORRECTION TO: PROTEIN CELL 2020, 11(7):525-533 HTTPS://DOI.ORG/10.1007/S13238-020-00696-9}

In the original publication the email addresses of corresponding authors have not been displayed. The correct email addresses of corresponding authors are provided in this correction. Fang-Cheng Li (sjwklfc@126.com), Fei Hu (neuron111@163.com), Min-Hua Luo (luomh@wh.iov.cn).

\section{OPEN ACCESS}

This article is licensed under a Creative Commons Attribution 4.0 International License, which permits use, sharing, adaptation, distribution and reproduction in any medium or format, as long as you give appropriate credit to the original author(s) and the source, provide a link to the Creative Commons licence, and indicate if changes were made. The images or other third party material in this article are included in the article's Creative Commons licence, unless indicated otherwise in a credit line to the material. If material is not included in the article's Creative Commons licence and your intended use is not permitted by statutory regulation or exceeds the permitted use, you will need to obtain permission directly from the copyright holder. To view a copy of this licence, visit http:// creativecommons.org/licenses/by/4.0/. 